\title{
Characterization of tillers in deferred Piata palisade grass with different initial heights and nitrogen levels
}

\author{
Braulio Maia de Lana Sousa ${ }^{1}$, Hélio Henrique Vilela ${ }^{1}$, Manoel Eduardo Rozalino Santos ${ }^{2}$, \\ Carlindo Santos Rodrigues ${ }^{3}$, Andreza Luzia Santos ${ }^{1}$, Domicio do Nascimento Júnior ${ }^{1}$, Camila \\ Zimmer de Assis ${ }^{1}$, Gabriel de Oliveira Rocha ${ }^{1}$
}

\footnotetext{
${ }^{1}$ Departamento de Zootecnia - UFV, Viçosa, MG.

2 Faculdade de Medicina Veterinária e Zootecnia - UFU, Uberlândia, MG.

${ }^{3}$ Instituto Federal de Educação, Ciências e Tecnologia Baiano - IF BAIANO - Núcleo de Ciências Agrárias, Campus Uruçuca, BA.
}

\begin{abstract}
This experiment was conducted to estimate the effects of nitrogen fertilization associated with the initial height of the Piata palisade grass on the number and structural characteristics of individual tillers after the deferment period. An area with Brachiaria brizantha cv. Piata measuring approximately $288 \mathrm{~m}^{2}$ was used. Combinations of levels of nitrogen fertilization (0, 75 and $150 \mathrm{~kg} / \mathrm{ha}$ of nitrogen) and initial heights of the sward (low $-20 \mathrm{~cm}$, medium - $30 \mathrm{~cm}$ and high - 40 $\mathrm{cm}$ ) were evaluated. The experimental design was of completely randomized blocks in subdivided plots with three replications. The number of vegetative tillers, the stem length of the vegetative, reproductive and dead tillers, and the number of dead leaves of the reproductive and the dead tillers linearly increased with the elevation in the nitrogen level. The deferred Piata palisade grass with low initial height showed lower number of dead basal tillers, shorter length of stems and leaf blades in reproductive tillers and lower number of live and dead leaves in vegetative tillers in relation to the one managed with height considered medium and high. Nitrogen fertilization, in association with low initial height, provides the optimization of forage of Piata palisade grass in deferment conditions.
\end{abstract}

Key Words: Brachiaria brizantha, seasonal production, tillering, tiller population density

\section{Introduction}

The seasonality of forage production on pastures generates the need for the use of strategies to provide the herd with food during periods of scarcity. Accordingly, the deferment of pasture is worth noting, especially in Central Brazil, because it is a simple strategy of management with relatively lower production cost: once the harvest of forage is performed by the animal itself, this strategy is considered easy to be used in pasture management. However, with the release of new cultivars of forage grasses, such as Piata palisade grass, it becomes necessary to carry out studies to determine the best strategy to use in deferment conditions.

The sward height has been guiding the management of tropical pastures during the rainy season, which is a favorable climate for plant growth, ensuring better efficiency of forage utilization (Barbosa et al., 2007; Pedreira et al., 2009; Difante et al., 2009; Sousa et al., 2010; Sousa et al., 2011). Under deferment conditions of the pasture usage, the initial height of the sward can influence the production, the morphological composition, the population density, and the characteristics of individual tillers of deferred pasture. This happens due to the effect of height on the leaf area remaining after the cutting, which determines the growth rate of tissues during the deferment period (Sousa et al., 2011).

Nitrogen fertilization can also modify the production and the structure of the deferred pasture (Santos et al., 2009a,b), once nitrogen increases the flow of tissues (growth and aging) of the grass, and, thus, the quantity of the different organs (leaves, stems) produced per unit time (Silva et al., 2008). In addition, nitrogen fertilization stimulates grass tillering (Fagundes et al., 2006), which may have as benefit the compensation of the deleterious effect of the deferment period on the tiller density (Santos et al., 2009b).

In this context, the comprehension of the response patterns of the tiller population, as well as their structural characteristics, in deferred pastures with sward height conditions and nitrogen fertilization variables at the beginning of the deferment, can help define appropriate strategies for management of Piata palisade grass under such conditions. 
Thus, this study was carried out with the objective of evaluating the effects of nitrogen fertilization and the initial height of the sward on the number and structural characteristics of individual tillers and, therefore, to identify deferment strategies for the use of the pasture that optimizes tillering and the structure of the Piata palisade grass.

\section{Material and Methods}

The experiment was conducted from 03/20 to 07/01/2010 in the Forage Sector of the Department of Animal Science, in the Universidade Federal deViçosa (UFV), located in Viçosa, Minas Gerais. The approximate geographic coordinates of the experiment location are $20^{\circ} 45^{\prime}$ south latitude and $42^{\circ} 51^{\prime}$ west longitude and the altitude is $651 \mathrm{~m}$.

An area with Brachiaria brizantha cv. Piata (Piata palisade grass), established in January 2009, on Red-Yellow clayey Latosol (EMBRAPA, 2006) was used. The experimental area measured approximately $288 \mathrm{~m}^{2}$.

According to Köppen, the climate of the region of Viçosa is the Cwa type, with annual rainfall around 1,340 mm and average relative air humidity of $80 \%$. Climatic data registered during the experimental period were obtained at the meteorological station of the Department of Agricultural Engineering at UFV, situated about $500 \mathrm{~m}$ from the experimental area (Table 1 ).

In early December 2009, sampling of soil was performed, in 0-20 cm layer, whose results of chemical analysis were: $\mathrm{pH}$ in $\mathrm{H}_{2} \mathrm{O}$ - 5.50; P - 1.40 (Mehlich-1) and $\mathrm{K}-36.00 \mathrm{mg} / \mathrm{dm}^{3}$; $\mathrm{Ca}^{2+}$ - 2.10; $\mathrm{Mg}^{2+}-0.70$ and $\mathrm{Al}^{3+}-0.00 \mathrm{cmol}_{\mathrm{c}} / \mathrm{dm}^{3}(\mathrm{KCl}$ $1 \mathrm{~mol} / \mathrm{L}$ ). Based on these results, liming was not done (EMBRAPA, 2008). At the beginning of the deferment period (03-20-2010) $50 \mathrm{~kg} / \mathrm{ha}$ of $\mathrm{P}_{2} \mathrm{O}_{5}$ were applied in the form of single superphosphate and $60 \mathrm{~kg} / \mathrm{ha}$ of $\mathrm{K}_{2} \mathrm{O}$, in the form of potassium chloride.

Combinations between nitrogen fertilization, randomized to the plots, and initial heights of the sward, randomized to the sub-plots were evaluated. The quantities of nitrogen used in the fertilization used were: 0.75 and $150 \mathrm{~kg} / \mathrm{ha}$. The initial heights of the sward were: low $(20 \mathrm{~cm})$, medium $(30 \mathrm{~cm})$ and high $(40 \mathrm{~cm})$. The design was of completely randomized blocks, in subdivided plots with three replications.

The experimental area was subdivided, with the aid of wooden stakes, in nine plots. Each plot was subdivided into three sub-plots of $10.6 \mathrm{~m}^{2}$ that, disregarding the border area, had a useful floor area of $5.0 \mathrm{~m}^{2}$.

All plants remained deferred for 103 days, with the beginning and the end of the deferment period on days $03 / 20 / 2010$ and $07 / 01 / 2010$, respectively. On the start date of the deferment, the height of the Piata palisade grass was $50 \mathrm{~cm}$ on average and, for the application of the treatments it was lowered by mechanical cutting to the respective evaluated heights (low, medium and high). At the deferment initial date, nitrogen doses were applied, in the form of ammonium sulfate, at one time in the late afternoon, according to the experimental treatments. Due to the use of ammonium sulfate, flower of sulfur was applied along with nitrogen in order to prevent any treatment from being favored by the higher amount of sulfur. After fertilization, the area was wet to raise the soil moisture and to reduce potential nitrogen losses by volatilization.

The evaluation of the number of tillers was performed by the collection of two samples in the floor area of the plot, at points that represented the average height of the sward. All tillers within a $0.25 \mathrm{~m}$ sidded square were harvested at the end of the deferment period (07/01/2010) by cutting at ground level. These tillers were placed in labeled plastic bags and then taken to the laboratory, where they were separated and quantified in basal or aerial tillers and in vegetative, reproductive or dead tillers. Basal tiller was considered that one originated from buds located near or close to the soil surface. The aerial tillers correspond to those originated from lateral buds on the main basal tiller. The tillers that had a visible inflorescence were classified as reproductive; the live tillers which had no visible inflorescences were called vegetative; and those whose stem was completely necrotic dead were classified as dead. The number of total tillers corresponded to the sum of basal and aerial tillers.

The structural characteristics of ten vegetative, reproductive and dead basal tillers were evaluated in each

Table 1 - Monthly means of minimum, mean, and maximum daily temperatures, total monthly rainfall and total monthly evaporation from March to July in 2010

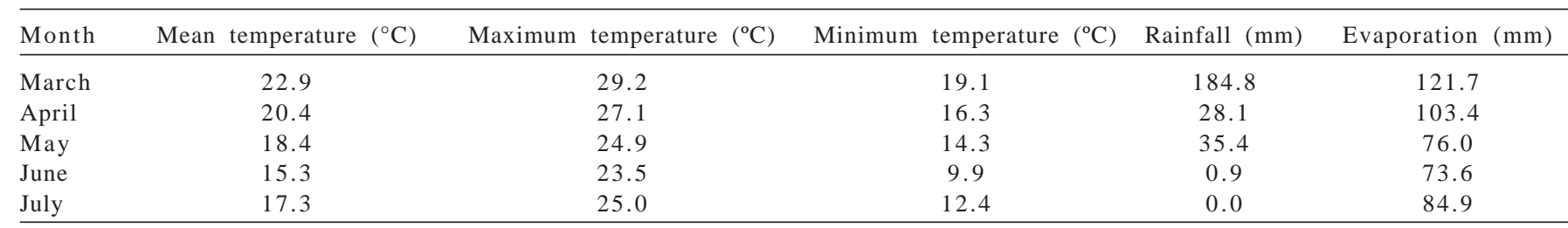


category per plot. In these tillers, the lengths of the pseudostem and leaf blade were quantified, as well as the numbers of live and dead leaves. The stem length was measured from the ground to the ligule of the oldest fully expanded leaf. The leaf blade length corresponded to the average length of fully expanded leaves. The live leaves consisted of expanding and expanded leaves. Only the leaves having over $50 \%$ of senescent leaf blade were classified as dead.

The analyses of experimental data were performed using SAEG (Sistema para Análises Estatísticas e Genéticas, version 8.1). For each characteristic, the analysis of variance was preceded. The comparison between the means of the levels of secondary factor (initial height of the sward) was performed by Tukey test. For the treatments of nitrogen levels, regression analyses were performed with selection of significant linear models. All analyses were performed at $5 \%$ probability of type I error.

\section{Results}

The variables analyzed were not influenced by the interaction between initial height of sward and nitrogen levels ( $\mathrm{P}>0.05)$. However, the variables were affected by the initial height of the sward and nitrogen $(\mathrm{P}<0.05)$.

The initial height did not influence the number of aerial vegetative, reproductive or dead tillers, nor did it alter the total number of tillers $(\mathrm{P}>0.05)$. The greatest sward height at the beginning of the deferment resulted in a lower number of basal vegetative tillers when compared with the low and medium heights $(\mathrm{P}<0.05)$. Lower number of basal reproductive tillers $(\mathrm{P}<0.05)$ was recorded in deferred Piata palisade grass with low initial height and higher in deferred pastures with high initial height. The deferred Piata palisade grass with low initial height presented lower $(\mathrm{P}<0.05)$ number of dead basal tillers in relation to the one deferred with medium and high initial height (Table 2).
The number of dead leaves of the reproductive and dead tillers, as well as the number of green leaves of the reproductive tiller did not vary with the initial height of the sward $(\mathrm{P}>0.05)$. However, the effect of initial height was observed for the other structural characteristics assessed in individual tillers. In general, longer length of the stem of reproductive, vegetative, and dead tillers occurred in plants deferred with high initial height, in relation to those deferred with medium initial height $(\mathrm{P}<0.05)$ and these variables showed higher values of these responses, when compared with plants deferred with low initial height (Table 3).

The length of the leaf blade of the reproductive tiller was higher $(\mathrm{P}<0.05)$ in deferred plants with high initial height, relatively to those deferred with low and medium initial height; the latter two did not differ. On the other hand, the length of the leaf blade of the vegetative tiller had increasing values as the initial height of the sward increased $(\mathrm{P}<0.05)$ (Table 3).

The number of live leaves of the vegetative tiller was higher $(\mathrm{P}<0.05)$ in deffered plants with high initial height, in relation to those deferred with low and medium initial height, which showed similar patterns. The number of dead leaves of the vegetative tiller showed the same response pattern $(\mathrm{P}<0.05)$ (Table 3).

The number of basal vegetative and total tillers increased linearly with the nitrogen level $(\mathrm{P}<0.05)$. The number of dead basal tillers decreased linearly with increase in the nitrogen level $(\mathrm{P}<0.05)$. On the other hand, there was no effect of nitrogen fertilization on the number of aerial vegetative, reproductive and dead tillers. ( $\mathrm{P}>0.05$ ) (Table 4 ).

The stem length of reproductive, vegetative and dead tillers, and the number of dead leaves of dead and reproductive tiller increased linearly with increase in the nitrogen level $(\mathrm{P}<0.05)$. In turn, there was no effect of nitrogen on the leaf blade length of the vegetative and reproductive tiller, the number of leaves in the vegetative and reproductive tiller or the number of dead leaves of vegetative tillers $(\mathrm{P}>0.05)$ (Table 5).

Table 2 - Number of tillers (tillers $/ \mathrm{m}^{2}$ ) of Piata palisade grass deferred at three initial heights

\begin{tabular}{|c|c|c|c|c|}
\hline \multirow[t]{2}{*}{ Tiller category } & \multicolumn{3}{|c|}{ Initial deferment height } & \multirow[t]{2}{*}{$\mathrm{P}$ value } \\
\hline & Low & Medium & High & \\
\hline Basal vegetative & $724 a(97.7)$ & $635 a(91.4)$ & $500 b(92.3)$ & 0.0046 \\
\hline Basal reproductive & $24 c(9.9)$ & $141 b(55.7)$ & $261 \mathrm{a}(26.6)$ & 0.0227 \\
\hline Basal dead & $64 b(23.5)$ & $88 a(17.6)$ & $100 a(13.6)$ & 0.0295 \\
\hline Aerial vegetative & $31(15.3)$ & $42(17.0)$ & $21(6.2)$ & 0.2283 \\
\hline Aerial reproductive & $0(0.1)$ & $0(0.3)$ & $11(5.2)$ & 0.3327 \\
\hline Aerial dead & $6(2.7)$ & $8(4.7)$ & $5(2.7)$ & 0.2412 \\
\hline Total & $780(92.7)$ & $785(86.6)$ & $774(126.9)$ & 0.9810 \\
\hline
\end{tabular}

Means followed by the same letter in the rows did not differ $(\mathrm{P}>0.05)$ by Tukey test.

Numbers inside parentheses correspond to the standard error of the mean. 
Table 3 - Structural characteristics of tillers of Piata palisade grass deferred at three initial heights

\begin{tabular}{|c|c|c|c|c|}
\hline Characteristic & \multicolumn{3}{|c|}{ Initial deferment height } & $\mathrm{P}$ value \\
\hline \multicolumn{5}{|l|}{ Reproductive tiller } \\
\hline Leaf blade length (cm) & 17.5b(1.6) & $18.2 b(1.4)$ & $20.7 \mathrm{a}(1.0)$ & 0.0265 \\
\hline Number of green leaves per tiller & $3.8(0.2)$ & $3.5(0.2)$ & $3.5(0.2)$ & 0.5302 \\
\hline Number of dead leaves per tiller & $3.8(0.3)$ & $4.2(0.4)$ & $4.3(0.3)$ & 0.4224 \\
\hline Stem length (cm) & $21.9 \mathrm{c}(1.8)$ & $38.6 b(4.3)$ & $58.8 \mathrm{a}(1.6)$ & 0.0256 \\
\hline Length of the leaf blade $(\mathrm{cm})$ & $16.3 c(0.9)$ & $27.7 b(1.4)$ & $38.0 \mathrm{a}(0.9)$ & 0.0003 \\
\hline Number of green leaves per tiller & $3.9 b(0.1)$ & $4.0 \mathrm{~b}(0.1)$ & $4.4 \mathrm{a}(0.1)$ & 0.0041 \\
\hline Number of dead leaves per tiller & $2.0 \mathrm{~b}(0.1)$ & $2.3 \mathrm{ab}(0.1)$ & $2.7 \mathrm{a}(0.3)$ & 0.0127 \\
\hline \multicolumn{5}{|l|}{ Dead tiller } \\
\hline Stem length (cm) & $40.0 c(8.6)$ & $50.9 b(7.8)$ & $60.6 \mathrm{a}(8.1)$ & 0.0002 \\
\hline
\end{tabular}

Means followed by the same letter in the rows did not differ $(\mathrm{P}>0.05)$ by Tukey test.

Numbers inside parentheses correspond to the standard error of the mean.

Table 4 - Number of tillers (tillers $/ \mathrm{m}^{2}$ ) of Piata palisade grass deferred with three nitrogen levels

\begin{tabular}{|c|c|c|c|c|c|c|}
\hline \multirow[t]{2}{*}{ Tiller category } & \multicolumn{3}{|c|}{ Nitrogen levels (kg/ha) } & \multirow[t]{2}{*}{ CV (\%) } & \multicolumn{2}{|c|}{$P$ value } \\
\hline & 0 & 75 & 150 & & $\mathrm{~L}$ & Q \\
\hline Basal vegetative ${ }^{1}$ & 275 & 774 & 811 & 13.51 & 0.0010 & 0.0524 \\
\hline Aerial vegetative & 43 & 46 & 5 & 41.52 & 0.1953 & 0.3551 \\
\hline Aerial reproductive & 2 & 8 & 0 & 24.36 & 0.4578 & 0.3122 \\
\hline Aerial dead & 6 & 12 & 0 & 30.25 & 0.2247 & 0.1014 \\
\hline
\end{tabular}

$\mathrm{CV}$ - coefficient of variation; $\mathrm{L}$ and $\mathrm{Q}$ - linear and quadratic effects, respectively, related to nitrogen inclusion.

$1 \hat{\mathrm{Y}}=352+3.5733 \times \mathrm{N}\left(\mathrm{r}^{2}=0.80\right)$.

$2 \hat{Y}=118.67-0.4667 \times \mathrm{N}\left(\mathrm{r}^{2}=0.91\right)$.

${ }^{3} \hat{Y}=513.33+3.64 \times N\left(r^{2}=0.78\right)$.

Table 5 - Structural characteristics of tillers of Piata palisade grass deferred with three nitrogen levels

\begin{tabular}{|c|c|c|c|c|c|c|}
\hline \multirow[t]{2}{*}{ Characteristic } & \multicolumn{3}{|c|}{ Nitrogen levels (kg/ha) } & \multirow[t]{2}{*}{ CV (\%) } & \multicolumn{2}{|c|}{$\mathrm{P}$ value } \\
\hline & 0 & 75 & 150 & & $\mathrm{~L}$ & Q \\
\hline \multicolumn{7}{|l|}{ Reproductive tiller } \\
\hline Leaf blade length $(\mathrm{cm})$ & 14.9 & 29.5 & 21.9 & 19.16 & 0.1912 & 0.5128 \\
\hline Number of green leaves per tiller & 3.9 & 3.7 & 3.4 & 19.72 & 0.1690 & 0.9290 \\
\hline Number of dead leaves per tiller ${ }^{2}$ & 3.5 & 4.5 & 4.4 & 13.95 & 0.0328 & 0.0692 \\
\hline Length of the leaf blade $(\mathrm{cm})$ & 25.6 & 28.7 & 27.8 & 12.64 & 0.2428 & 0.2230 \\
\hline Number of green leaves per tiller & 4.2 & 4.1 & 4.1 & 8.43 & 0.4939 & 0.7404 \\
\hline Number of dead leaves per tiller & 2.3 & 2.5 & 2.2 & 14.46 & 0.6479 & 0.0975 \\
\hline \multicolumn{7}{|l|}{ Dead tiller } \\
\hline Stem length $(\mathrm{cm})^{4}$ & 26.3 & 48.6 & 76.7 & 24.53 & 0.0010 & 0.5985 \\
\hline
\end{tabular}

$\mathrm{CV}$ - coefficient of variation; L and Q: linear and quadratic effects, respectively, related to nitrogen inclusion.

${ }^{1} \hat{\mathrm{Y}}=58.50+0.166 \times \mathrm{N}\left(\mathrm{r}^{2}=0.96\right)$.

$2 \hat{Y}=3.68+0.006 \times N\left(r^{2}=0.67\right)$.

${ }^{3} \hat{\mathrm{Y}}=34.15+0.075 \times \mathrm{N}\left(\mathrm{r}^{2}=0.89\right)$.

${ }^{4} \hat{\mathrm{Y}}=25.33+0.336 \times \mathrm{N}\left(\mathrm{r}^{2}=0.99\right)$.

${ }^{5} \hat{\mathrm{Y}}=5.75+0.011 \times \mathrm{N}\left(\mathrm{r}^{2}=0.92\right)$. 


\section{Discussion}

The use of pasture deferment enables forage supply in times of scarcity. However, the long time that the grass remains without defoliation (deferment period) results in intraspecific competition of the plants, which negatively influences their structural characteristics, especially their tiller density. In this way, proper management of the pasture at the beginning of the deferment period can optimize tillering and the structural characteristics of the tillers.

It this context, it was clear that the decrease in initial height of the sward reduced the number of reproductive tillers of the deferred pasture (Table 2). This feature is desirable in deferred pastures, once, in grasses in the reproductive stage, the seed acts as a strong drain, reallocating the photoassimilates for its development (Hopkins, 1995). Moreover, during the formation of the inflorescence, stem elongation occurs over the synthesis of new leaves, which contributes to the reduction in the nutritive value of pasture (Van Soest, 1994). This decline in the number of reproductive tillers with a reduction in the initial height of the sward (Table 2) may be due to greater elimination of the apical meristem of older tillers, which provided larger renewal of the tiller population (Taiz \& Zeiger, 2009).

In contrast, when the Piata palisade grass was deferred with low and medium initial height, there was higher number of basal vegetative tillers in relation to the plants deffered with high initial height (Table 2). The lower number of basal vegetative tillers in taller deferred plants probably occurred because of the greater competition for light between the tillers in this condition (Langer, 1963). The increase of the initial height of the sward increases the leaf area at the beginning of the pasture regrowth (Sousa et al., 2010, 2011), which reduces the quantity and the quality of the light that penetrates into the sward and thereby inhibits the emergence of new tillers (Sbrissia et al., 2010), in addition to causing their mortality (Table 2).

Associated with the high number of reproductive tillers, long stem length of vegetative and reproductive tillers at greater sward height at the beginning of the deferment (Table 3) or nitrogen level (Table 5) was also recorded. The more developed stem contributes to the reduction of the nutritive value of pasture (Santos et al., 2010), besides impairing the ingestive behavior and animal performance (Carvalho et al., 2006). In fact, the elongation of the stem alters the pasture structure, with negative effects on forage intake (Palhano et al., 2007; Trindade et al., 2007) and efficiency of forage utilization (Carnevalli et al., 2006).
The longer stem length of both the vegetative and reproductive tillers at the greater sward height at the beginning of the deferment contributed to the longer leaf blade length (Table 3). In tillers with longer stems, the distance traveled by a leaf from the point of connection to the meristem until the end of the pseudostem is greater, resulting in its longer length (Skinner \& Nelson, 1995).

The deferred Piata palisade grass with high initial height probably remained longer with leaf area index (LAI) higher than the critical LAI, from which competition for light in the sward begins. In this condition, the process of stem elongation is emphasized, as well as the senescence process of the leaves located in the lower stratum of the pasture (Da Silva \& Nascimento Júnior, 2007). Hence, there was a greater number of dead leaves of vegetative tillers and greater stem length of the dead tiller (Table 3 ).

The adoption of low initial height of the plants $(20 \mathrm{~cm})$ at the beginning of the deferment period increased the number of basal reproductive tillers and decreased the number of reproductive and dead basal tillers (Table 2), and reduced the length of stems in vegetative, reproductive and dead tillers (Table 3). Considering this effect, one can infer that it must be deferred with lower initial height $(20 \mathrm{~cm})$. The maintenance of high pastures at the beginning of the deferment period would increase competition for light in the sward, which would result in decrease in tillering and undermine the structural characteristics of individual tillers in deferred pasture (Tables 2 and 3).

As for nitrogen, its effect is related to the improvement of soil fertility, which promotes significant increase in the flow of forage plant tissues (Duru \& Ducrocq, 2000), including the greater emergence of tillers under conditions of increased fertilization (Table 4). This contributes to the intensification of the competition for light in the sward and, with effect, leads to higher elongation and length of the stem of the tillers (Table 5).

The increase in the flow of tissues in forage grasses under conditions of nitrogen fertilization was observed by Garcez Neto et al. (2002) and Alexandrino et al. (2004). These authors reported that the nitrogen application increased the leaf elongation and the tillering of tropical grasses. With the Piata palisade grass in deferment conditions, higher numbers of vegetative tillers and total tillers, in the conditions of fertilization with nitrogen, were observed (Table 4). Actually, with 103 days of deferment, the increase in the number of total vegetative tillers was $116 \%$ and $128 \%$ when using 75 and $150 \mathrm{~kg} / \mathrm{h}$ of nitrogen, respectively, compared with the level of $0 \mathrm{~kg} / \mathrm{ha}$ nitrogen. Santos et al. (2009b) also reported increase in the number 
of vegetative tillers in fertilized and deferred $B$. decumbens pastures.

The leaf blade length of reproductive tillers increased linearly with the dose of nitrogen (Table 5). This result may have occurred due to the increase in leaf elongation provided by the greater availability of nitrogen in the soil (Mazzanti et al., 1994; Martuscello et al., 2005; Martuscello et al., 2006; Oliveira et al., 2007). Moreover, as already mentioned, the greater length of the stem in the tillers contributes to the longer leaf blade length (Skinner \& Nelson, 1995).

The increase of flow of tissues in tropical grasses promoted by nitrogen fertilization may cause negative effect on the structure of the pasture, since the rate of senescence is marked in this condition (Alexandrino et al., 2004; Martuscello et al., 2005; Martuscello et al., 2006). In fact, during the vegetative stage, growth is projected in the process of senescence (Parsons et al., 1983); however, in the reproductive stage, when the emission of leaves ceases, the leaf senescence process is more evident. These processes occur under deferment conditions, in which the plant goes through a long period without defoliation, which explains the higher number of dead leaves in the reproductive tiller and in the dead tiller (Table 5).

However, in the case of the number of dead basal tillers, it decreased linearly with the dose of nitrogen (Table 4). This fact highlights the importance of nitrogen to maintain a younger tiller profile in deferred pasture and thus ensure the continuity of the pasture. There is evidence that the age of tillers influences the morphogenetic and structural characteristics, resulting in progressive loss of vigor with advancing tiller age (Montagner et al., 2011; Paiva et al., 2012).

Considering the positive effect of the use of the deferred Piata palisade grass on the number of vegetative tillers and the negative effect on the number of dead tillers (Table 4), the fertilization of Piata palisade grass with nitrogen at the beginning of the deferment is suggested. Tillering and tiller structural characteristics had little or no difference between 75 and $150 \mathrm{~kg} / \mathrm{ha}$ of nitrogen levels (Tables 4 and 5). Thus, it is recommended to use $75 \mathrm{~kg} / \mathrm{ha}$ of nitrogen to the deferred Piata palisade grass for 103 days. However, it appears that, to enjoy the benefits of increased nitrogen fertilization (150 kg/ha) on the tillering and structural characteristics of individual tillers, Piata palisade grass should be deferred for a period of less than 103 days, in order to increase the rate of the pasture growth without damaging their structural characteristics. The adoption of shorter periods of deferment concomitantly to the use of high doses of nitrogen could result in quality forage similar to pastures managed with lower nitrogen levels and longer periods of deferment (Fonseca \& Santos, 2009).

\section{Conclusions}

To stimulate tillering and improve the structural characteristics of individual tillers of the deferred Piata palisade grass, the recommendation is deferring it with low initial height $(20 \mathrm{~cm})$ and with nitrogen fertilization ( $75 \mathrm{~kg} / \mathrm{ha})$ at the beginning of deferment.

\section{References}

ALEXANDRINO, E.; NASCIMENTO JÚNIOR, D.; MOSQUIM, P.R. et al. Características morfogênicas e estruturais na rebrotação da Brachiaria brizantha cv. Marandu submetida a três doses de nitrogênio. Revista Brasileira de Zootecnia, v.33, p.1372-1379, 2004.

BARBOSA, R.A.; NASCIMENTO JÚNIOR, D.; EUCLIDES, V.P.B. et al. Capim-tanzânia submetido a combinações entre intensidade e frequência de pastejo. Pesquisa Agropecuária Brasileira, v.42, n.3, p.329-340, 2007.

CARNEVALLI, R.A.; DA SILVA, S.C.; BUENO, A.A.O. et al. Herbage production and grazing losses in Panicum maximum cv. Mombaça under four grazing managements. Tropical Grasslands, v.40, p.165-176, 2006.

CARVALHO, C.F.; GONSALVES, E.N.; POLI, C.H.E.C. et al. Ecologia do pastejo. In: SIMPÓSIO SOBRE MANEJO ESTRATÉGICO DA PASTAGEM, 3., 2006, Viçosa, MG. Anais... Viçosa, MG: UFV, 2006. p.43-72.

DA SILVA, S.C.; NASCIMENTO JÚNIOR, D. Avanços na pesquisa com plantas forrageiras tropicais em pastagens: características morfofisiológicas e manejo do pastejo. Revista Brasileira de Zootecnia, v.36, p.121-138, 2007 (suplemento especial).

DA SILVA, S.C.; NASCIMENTO JÚNIOR, D.; EUCLIDES, V.B.P. Pastagens: conceitos básicos, produção e manejo. Viçosa, MG: Suprema, 2008. 115p.

DIFANTE, G.S.; NASCIMENTO JÚNIOR, D.; EUCLIDES, V.P.B. et al. Sward structure and nutritive value of Tanzania guinea grass subjected to rotational stocking managements. Revista Brasileira de Zootecnia, v.38, p.9-19, 2009.

DURU, M.; DUCROCQ, H. Growth and senescence of the successive grass leaves on a tiller. Ontogenic development and effect of temperature. Annals of Botany, v.85, p.635-643, 2000.

EMPRESA BRASILEIRA DE PESQUISA AGROPECUÁRIA EMBRAPA. Serviço Nacional de Levantamento e Conservação de Solos. Sistema brasileiro de classificação de solos. 2.ed. Rio de Janeiro: Embrapa Solos, 2006. 306p.

EMPRESA BRASILEIRA DE PESQUISA AGROPECUARIA EMBRAPA. Informativo Piatã, ano 1, 2.ed, 2008. 3p.

FAGUNDES, J.L.; FONSECA, D.M.; MORAIS, R.V. et al. Avaliação das características estruturais do capim-braquiária em pastagens adubadas com nitrogênio nas quatro estações do ano. Revista Brasileira de Zootecnia, v.35, p.30-37, 2006.

FONSECA, D.M.; SANTOS, M.E.R. Diferimento de pastagens: Estratégias e ações de manejo. In: SIMPÓSIO DE FORRAGICULTURA E PASTAGEM, 6.; CONGRESSO DE FORRAGICUlTURA E PASTAGEM, 3., 2009, Lavras. Anais... Lavras: UFLA, 2009. p.65-88.

GARCEZ NETO, A.F.; NASCIMENTO JÚNIOR, D.; REGAZZI, A.J. et al. Respostas morfogênicas e estruturais de Panicum maximum cv. Mombaça sob diferentes níveis de adubação nitrogenada e alturas de corte. Revista Brasileira de Zootecnia, v.31, n.5, p.1890-1900, 2002.

HOPKINS, W.G. Introduction to plant physiology. Toronto: John Wiley \& Sons, 1995. 649p.

LANGER, R.H.M. Tillering in herbage grass: a review. Herbage Abstracts, v.33, p.141-148, 1963. 
MARTUSCELLO, J.A.; FONSECA, D.M.; NASCIMENTO JÚNIOR, D. Características morfogênicas e estruturais do capim-xaraés submetido à adubação nitrogenada e desfolha. Revista Brasileira de Zootecnia, v.34, p.1475-1482, 2005.

MARTUSCELLO, J.A.; FONSECA, D.M.; NASCIMENTO JÚNIOR, D. et al. Características morfogênicas e estruturais do capimmassai submetido à adubação nitrogenada e desfolhação. Revista Brasileira de Zootecnia, v.35, p.665-672, 2006.

MAZZANTI, A.; LEMAIRE, G.; GASTAL, F. The effect of nitrogen fertilization upon herbage production of tall fescue swards grazed by shepp. 1. Herbage growth dynamics. Grass and Forage Science, v.49, p.111-120, 1994.

MONTAGNER, D.B.; NASCIMENTO JÚNIOR, D.; SOUSA, B.M.L. et al. Morphogenetic and structural characteristics of tillers of guinea grass of different age and grazing severities. Revista Brasileira de Zootecnia, v.40, p.2105-2110, 2011.

OLIVEIRA, A.B.; PIRES, A. J.V.; NETO, W.M. et al. Morfogênese do capim-tanzânia submetido a adubações e intensidade de cortes. Revista Brasileira de Zootecnia, v.36, n.4, p.1006-1013, 2007.

PALHANO, A.L.; CARVALHO, P.C.F.; DITTRICH, J.R. et al. Característica do processo de ingestão de forragem por novilhas holandesas em pastagem de capim-mombaça. Revista Brasileira de Zootecnia, v.36, p.1014-1021, 2007.

PAIVA, J.A.; Da SILVA, S.C.; PEREIRA, L.E.T. et al. Structural characteristics of tiller agecategories of continuously stoked Marandu palisade grass swards fertilized of nitrogen. Revista Brasileira de Zootecnia, v.41, p.24-29, 2012.

PARSONS, A.J.; LEAFE, E.L.; COLLETT, B. et al. The physiology of grass production under grazing. II. Photosynthesis, crop growth and animal intake of continuously-grazed swards. Journal of Applied Ecology, v.20, p.127-139, 1983.

PEDREIRA, B.C.; PEDREIRA, C.G.S.; DA SILVA, S.C. Acúmulo de forragem durante a rebrotação de capim-xaraés submetido a três estratégias de desfolhação. Revista Brasileira de Zootecnia, v.38, p.618-625, 2009.
SANTOS, M.E.R.; FONSECA, D.M.; BALBINO, E.M. et al. Capimbraquiária diferido e adubado com nitrogênio: produção e características da forragem. Revista Brasileira de Zootecnia, v.38, p.650-656, 2009a.

SANTOS, M.E.R.; FONSECA, D.M.; BALBINO, E.M. et al. Caracterização dos perfilhos em pastos de capim-braquiária diferidos e adubados com nitrogênio. Revista Brasileira de Zootecnia, v.38, p.643-649, 2009b.

SANTOS, M.E.R.; FONSECA, D.M.; BALBINO, E.M. et al. Valor nutritivo de perfilhos e componentes morfológicos em pastos de capim-braquiária diferidos e adubados com nitrogênio. Revista Brasileira de Zootecnia, v.39, p.1919-1927, 2010.

SBRISSIA, A.F.; DA SILVA, S.C.; SARMENTO, D.O.L. et al. Tillering dynamics in Marandu palisadegrass swards continuously stocked by cattle. Plant Ecology, v.206, p.349-359, 2010.

SKINNER, R.H.; NELSON, C.J. Elongation of the grass leaf and its relationship to the phyllochon. Crop Science, v.35, p.4-10, 1995.

SOUSA, B.M.L.; NASCIMENTO JÚNIOR, D.; DA SILVA, S.C. et. al. Morphogenetic and structural characteristics of Andropogon grass submitted to different cutting heights. Revista Brasileira de Zootecnia, v.39, p.2141-2147, 2010.

SOUSA, B.M.L.; NASCIMENTO JÚNIOR, D.; RODRIGUES, C.S. et al. Morphogenetic and structural characteristics of Xaraes palisadegrass submitted to cutting heights. Revista Brasileira de Zootecnia, v.40, p.53-59, 2011.

TAIZ, L.; ZEIGER, E. Fisiologia vegetal. 4.ed. Tradução SANTARÉM, E.R. et al. Porto Alegre: Artmed, 2009. 848p.

TRINDADE, J.K.; DA SILVA, S.C.; SOUZA JÚNIOR, S.J. et al. Composição morfológica da forragem consumida por bovinos de corte durante o rebaixamento do capim-marandu submetido a estratégias de pastejo rotativo. Pesquisa Agropecuária Brasileira, v.42, p.883-890, 2007.

VAN SOEST, P.J. Nutritional ecology of the ruminant. 2.ed. New York: Cornell University Press, 1994. 476p. 